\title{
Faktor-Faktor yang Mempengaruhi Penggunaan Kontrasepsi Implant
}

\author{
Erma Sugiana $^{1,2 *}$, ST Aisjah Hamid ${ }^{3}$, Erma Puspita Sari ${ }^{4}$ \\ ${ }_{1,3,4}$ Universitas Kader Bangsa, Jln HM Ryacudu No 887 Ulu Palembang Sumatera Selatan \\ ${ }^{2}$ UPTD Puskesmas Gumawang, Jl.Mayjend Warsito No.1 Desa Gumawang, Belitang, OKU Timur Sumatera Selatan \\ "Correspondence email: ermasugiananasir@gmail.com
}

\begin{abstract}
Abstrak. Implant merupakan alat kontrasepsi hormonal yang efektif dan efisien berbentuk batang yang ditanamkan di bawah kulit yaitu pada bagian lengan atas, dan jangka waktu perlindungan dapat mencapai lima tahun. Tujuan penelitian ini adalah ingin mengetahui faktor-faktor yang mempengaruhi penggunaan kontrasepsi implant. Penelitian ini merupakan survei analitik dengan desain penelitian cross sectional, penelitian dilakukan pada bulan Juni - Agustus Tahun 2020 di Puskesmas Gumawang Kab. Oku Timur Sumatera Selatan, Populasi dalam penelitian ini adalah semua pasangan usia subur yang menggunakan KB yang berkunjung di Puskesmas di Puskesmas Gumawang Kab. Oku Timur yang diperkirakan berjumlah 7.729 akseptor dan Sampel yang digunakan pada penelitian ini adalah sebagian dari ibu pengguna KB yang berkunjung di UPTD Puskesmas Gumawang Kab. Oku Timur Tahun 2019 yang berjumlah 99 orang, melalui Proportional Random Sampling, analisis univariat (proporsi), bivariat (uji chi square) dan multivariat (regresi logistik). Hasil analisis menunjukkan bahwa paritas (p value:0,004) dan umur ( $\mathrm{p}$ vaue:0,028), pekerjaan ( $\mathrm{p}$ value:0,001), memiliki hubungan signifikan dengan penggunaan KB Implan, sedangkan pendidikan ( $\mathrm{p}$ value:0,089) tidak memiliki hubungan yang signifikan dengan penggunaan KB Implan. Berdasatkan model akhir analisis multivariat variabel yang paling besar pengaruhnya terhadap penggunaan KB Implan adalah variabel pekerjaan.Diharapkan dari hasil penelitian ini dapat meningkatkan peran aktif bidan untuk memberikan KIE tentang kelebihan dan kekurangan metode kontrasepsi yang akan dipilih akseptor yang sesuai dengan tujuan dan umurnya.
\end{abstract}

Kata kunci: Anemia; Paritas; Pekerjaan; Pendidikan; Umur

Abstract. The implant is an effective and efficient hormonal contraceptive in the form of a rod that is implanted under the skin in the upper arm, and the protection period can be up to five years. The purpose of this study was to determine the factors that influence implant contraceptive use. This research is an analytical survey with a cross sectional research design, the study was conducted in June - August 2020 at Puskesmas Gumawang Kab. Oku Timur South Sumatra. The population in this study were all couples of childbearing age who used family planning who visited the Puskesmas in Puskesmas Gumawang Kab. East Oku, which is estimated to be 7,729 acceptors and the sample used in this study were some of the mothers who used family planning who visited the UPTD Puskesmas Gumawang Kab. East Oku in 2019, amounting to 99 people, through Proportional Random Sampling, univariate (proportion), bivariate (chi square test) and multivariate (logistic regression) analysis. The results of the analysis showed that parity ( $p$ value: 0.004) and age ( $p$ value: 0.028), occupation ( $p$ value: 0.001), had a significant relationship with the use of family planning implants, while education ( $p$ value: 0.089 ) had no significant relationship with use of implant birth control. Based on the final model of multivariate analysis, the variable that has the greatest influence on the use of implant family planning is the occupational variable. It is hoped that the results of this study can increase the active role of midwives to provide IEC about the advantages and disadvantages of contraceptive methods that acceptors will choose according to their goals and age.

Keywords: Anemia; Parity; Occupation; Education; Age

\section{PENDAHULUAN}

Jumlah penduduk yang terus meningkat merupakan masalah besar bagi negara- negara di dunia, khususnya negara berkembang. Indonesia merupakan negara berkembang dengan jumlah penduduk terbesar ke empat setelah Cina, India dan Amerika Serikat. Dari data sensus tahun 2015 diketahui bahwa penduduk Indonesia berjumlah 238.518.000 jiwa dan diproyeksikan pada 2020 akan meningkat sebanyak 271.066.000 jiwa. Data dalam Survei Demografi dan Kesehatan Indonesia (SDKI) Tahun 2017 memperlihatkan kemajuankemajuan yang dicapai program keluarga berencana (KB) dalam 5 tahun terakhir dan kontribusinya terhadap situasi transisi demografi di Indonesia. Total fertility rate (TFR) Indonesia mengalami penurunan sebanyak 0,2 poin dari 2,6 per wanita usia subur pada pada SDKI
Tahun 2012 menjadi 2,4 per wanita usia Subur pada SDKI Tahun 2017. (SDKI, 2017).

Menurut World Health Organization (WHO, 2014) penggunaan kontrasepsi telah meningkat di banyak bagian dunia, terutama di Asia dan Amerika Latin dan terendah di Sub Sahara Afrika. Secara global, pengguna kontrasepsi modern telah meningkat tidak signifikan dari 54\% pada tahun1990 menjadi 57,4\% pada tahun 2014. Secara regional, proporsi pasangan usia subur 15-49 tahun melaporkan penggunaan metode kontrasepsi modern telah meningkat minimal 6 tahun terakhir. Di Afrika dari 23,6\% menjadi27,6\%, di Asia telah meningkat dari $60,9 \%$ menjadi $61,6 \%$, sedangkan Amerika latin dan Karibia naik sedikit dari $66,7 \%$ menjadi $67,0 \%$. 
KB merupakan salah satu strategi untuk mengurangi kematian ibu khususnya ibu dengan kondisi 4T yaitu Terlalu muda melahirkan (di bawah usia 20 tahun), Terlalu sering melahirkan, Terlalu dekat jarak melahirkan, dan Terlalu tua melahirkan (di atas usia 35 tahun). Selain itu, program KB juga bertujuan untuk meningkatkan kualitas keluarga agar dapat timbul rasa aman,tentram, danharapan masa depan yang lebih baik dalam mewujudkan kesejahteraan lahir dan kebahagiaan batin. Salah satu alat kontrasepsi permanen atau mantap yang jarang digunakan adalah implant. (Samekto, 2008).

Implant merupakan alat kontrasepsi hormonal yang efektif dan efisien berbentuk batang yang ditanamkan di bawah kulit yaitu pada bagian lengan atas, dan jangka waktu perlindungan dapat mencapai lima tahun. Keuntungannya adalah dapat dicabut setiap saat sesuai kebutuhan, tidak mengandung zat aktif berisiko (bebas estrogen), tidak menganggu kegiatan senggama, setelah pencabutan. Walaupun tingkat efektivitas implant tinggi tetapi penggunaannya cukup rendah. (Samekto, 2008).

Untuk data 2019 tercatat penggunaalat kontrasepsi. KB aktif mencapai 93.662 peserta atau $(80,0 \%)$ dari jumlah PUS 117.105 jiwa. Untuk pemakai kontrasepsi. pengguna paling banyak adalah metode suntikan sebesar 53969 peserta $(57,6 \%)$, pil sebesar 24.129 peserta $(25,8 \%)$, pengguna implant sebesar 7.416 peserta $(7,9 \%)$, pengguna Intra Uterin Devices (IUD) sebesar 938 peserta $(1,0 \%)$, kondom sebesar 6.832 peserta $(7,3 \%)$, Metode Operasi Wanita (MOW) sebesar 279 peserta $(0,3 \%)$, Metode Operasi pria (MOP) sebesar 89 peserta $(0,1 \%)$. (BKBKS Kab. OKUT, 2019).

Pada tahun 2017 data akseptor KB aktif di UPTD Puskesmas Gumawangsebanyak 6.529 jiwa $(74,1 \%)$ dari PUS sebanyak 8.811 jiwa, MOP sebanyak $51(0,8 \%)$, MOW sebanyak 294 (4,5\%), Implant sebanyak 1.474 $(22,6 \%)$, Kondom sebanyak 1.021 (15,6\%), Suntik sebanyak $1.161(17,8 \%)$, IUD sebanyak $1.104(16,9 \%)$ dan Pil sebanyak 1.424 (21,8\%). Tahun 2018 data akseptor KB aktif sebanyak 6.889 (75,3\%) dari jumlah PUS sebanyak 9.143 jiwa, MOP sebanyak $84(0,8 \%)$, MOW sebanyak 100 (1,0\%), Implant sebanyak 1,984 $(19,6 \%)$, Kondom sebanyak 1.378 (13,6\%), Suntik sebanyak $5.828(57,5 \%)$, IUD sebanyak $593(5,8 \%)$ dan Pil sebanyak 177 (1,7\%). Tahun 2019 data akseptor KB aktif adalah sebanyak 7.729 (82,98\%) dari jumlah PUS sebanyak 9.314 jiwa, MOP sebanyak $39(0,5 \%)$, MOW sebanyak 75 (0.97\%), Implant sebanyak 2,263 $(29,3 \%)$, Kondom sebanyak $639(8,27 \%)$, Suntik sebanyak $2.772(35,86 \%)$, IUD sebanyak $420(5,43 \%)$ dan Pil sebanyak $1.521(19,67 \%)$.

Teori Health Belief Model (HB) Lewin (1954) dalam Notoatmodjo (2008) mengungkapkan bahwa rendahnya minat MKJP dipengaruhi oleh persepsi individu mengenai ancaman dan pertimbangan untung rugi. Persepsi individu dipengaruhi faktor yaitu usia, pendidikan, pengetahuan, jumlah anak, paparan sumber informasi dan kondisi ekonomi. Sehubungan dengan teori HBM, kecenderungan yang ada saat ini berdasarkan penelitian adalah bahwa MKJP cenderung diminati oleh ibu yang berusia kurang produktif $(>30$ tahun), memiliki anak lebih dari 2 orang, berpendidikan menengah, berpengetahuan MKJP , pendapatan di atas UMR, presepsi MKJP positif dan paparan sumber informasi (Sari, 2016).

Penelitian Anantasia Marliza (2013) menyimpulkan Pengetahuan, pendidikan dan pengalaman yang diperoleh responden dari orang lain tentang adanya kemungkinan mendukung responden untuk tidak menggunakan kontrasepsi implant jadi membuat mereka tidak termotivasi untuk memilih alat kontrasepsi tersebut, pendapatan kecil mendukung orang untuk tidak menggunakan kontrasepsi implant karena secara umum mereka menyatakan KB itu mahal.

Penelitian yang dilakukan oleh Kadir (2012) dengan judul Hubungan Paritas dan Pekerjaan Akseptor dengan Pemakaian Kontrasepsi Impant di BPS Kresna Hawati Kel. Karang Jaya Palembang menunjukkan ada hubungan bermakna antara paritas dan pekerjaan akseptor dengan pemakaian kontrasepsi implant, responden yang bekerja lebih memilih MKJP sehingga tidak perlu berulang kali melakukan kunjungan ke tenaga pelayanan $\mathrm{KB}$, wanita yang bekerja cenderung untuk lebih mengatur kesuburannya sehingga mereka harus memilih kontrasepsi yang paling efektif dan berlangsung dalam jangka waktu lama dan responden yang memiliki paritas tinggi menjadi akseptor implant disebabkan ingin membatasi kelahiran atau tidak ingin menambah anak lagi tetapi belum siap untuk sterilisasi. Tujuan penelitian ini adalah ingin mengetahui faktorfaktor yang mempengaruhi penggunaan kontrasepsi Implan.

\section{METODE}

Penelitian ini merupakan survei analitik dengan desain penelitian cross sectional, penelitian dilakukan pada juni-agustus 2020 di Puskesmas Gumawang Kab. Oku Timur.

Populasi dalam penelitian ini adalah semua pasangan usia subur yang menggunakan KB yang berkunjung di Puskesmas di Puskesmas Gumawang Kab. Oku Timur yang diperkirakan berjumlah 7.729 akseptor dan Sampel yang digunakan pada penelitian ini adalah sebagian dari ibu pengguna KB yang berkunjung di UPTD Puskesmas Gumawang Kab. Oku Timur Tahun 2019 yang berjumlah 99 orang. Pada penelitian ini pengumpulan data dilakukan dengan cara mengumpulkan data sekunder. Data skunder di peroleh dengan cara mengumpulkan jumlah data populasi dengan menggunakan teknik Sampling Random Sistematik. Dimana data diperoleh dari data rekam medis di Puskesmas Gumawang Kabupaten Oku Timur tahun 2019. 
Data diolah dengan program SPSS 22.0 for windows. Analisis data menggunakan analisis univariat, bivariat dan multivariat. Analisis univariat untuk melihat distribusi frekuensi dan proforsi masing masing faktor faktor yang termasuk dalam penelitian. Analisis bivariat untuk mengetahui hubungan variabel independent dan dependent sekaligus untuk melakukan identifikasi variabel yang bermakna dengan dilakukan Uji ChiSquare, dengan menggunakan perangkat lunak program SPSS dengan batas kemaknaan $\alpha: 0,05$ keputusan hasil statistic di peroleh dengan cara membandingkan nilai $p$ (p value) dengan nilai $\alpha$.

Analisis multivariat untuk melihat hubungan antara variabel dependen dengan beberapa variabel independent dan mencari variabel mana yang paling dominan berhubungan kemudian dilakukan Uji interaksi. Dalam analisis multivariate ini digunakan metode analisis regresi logistic tujuanya adalah untuk mendapatkan variabel yang paling dominan, dikarenakan variabel dependen adalah variabel dikotom dan variabel independent kategorikal. (Sutanto, 2018).

\section{HASIL DAN PEMBAHASAN Analisis Univariat}

Penelitian ini dilakukan pada 99 responden. Dari hasil penelitian diperoleh bahwa responden yang menggunakan KB Implan terdapat lebih banyak yaitu 52 orang $(53,1 \%)$ di bandingkan dengan responden yang tidak menggunakan KB Implan yang terdapat 46 orang $(46,9 \%)$ (Tabel 1).

Tabel 1. Distribusi Frekuensi Variabel Independen dan Dependen.

\begin{tabular}{clcc}
\hline No & \multicolumn{1}{c}{ Variabel Penelitian } & Total & Persentase (\%) \\
\hline 1 & Pendidikan & & \\
& 1. Tinggi & 50 & 50,5 \\
& 2. Rendah & 49 & 49,5 \\
2 Paritas & & \\
& 1. Tinggi & 32 & 32,3 \\
& 2. Rendah & 67 & 67,7 \\
3 & Umur & & \\
& 1. Risiko Tinggi & 53 & 53,5 \\
& 2. Risiko Rendah & 46 & 46,5 \\
4 & Pekerjaan & 51 & 51,5 \\
& 1. Berat & 48 & 48,5 \\
& 2. Ringan & & \\
& Penggunaan KB Implan & & 51,5 \\
& 1. Ya & 29 & 48,5 \\
\hline & 2. Tidak & 70 &
\end{tabular}

Sumber: Data diolah

\section{Analisis Bivariat \\ Hubungan Pendidikan Dengan Penggunaan KB Implan}

Hasil analisis hubungan antara pendidikan dengan penggunaan KB Implan diperoleh bahwa ada sebanyak 19 responden $(38,0 \%)$ yang menggunakan KB Implan dan 31 responden $(62,0 \%)$ yang tidak tidak menggunakan KB Implan dari sejumlah 50 responden yang Tinggi. Hasil uji statistik diperoleh nilai $\mathrm{p}=0,089$, maka dapat disimpulkan bahwa secara statistik pada alpa 0,05 tidak ada hubungan yang signifikan antara pendidikan dengan penggunaan KB Implan di Puskesmas Gumawang Kab. OKU Timur Sumatera Selatan Tahun 2020.

Peran pendidikan dalam mempengaruhi pola pemikiran wanita untuk menentukan kontrasepsi mana yang lebih sesuai untuk dirinya, kecenderungan ini menghubungkan antara tingkat pendidikan akan mempengaruhi pemahaman dan pengetahuan seseorang, berdasarkan penelitian di Cambodia menegaskan tentang hubungan pendidikan dengan pemilihan kontrasepsi modern sangat berkaitan (Samandari, 2010).

Pendidikan merupakan salah satu kebutuhan dasar manusia yang sangat diperlukan dan memiliki pengaruh pada peningkatan kemampuan berpikir, dengan kata lain seseorang yang berpendidikan lebih tinggi akan dapat mengambil keputusan yang lebih rasional, umumnya terbuka untuk menerima perubahan atau hal baru dibandingkan dengan individu yang berpendidikan lebih rendah.

Hasil penelitian ini sejalan dengan penelitian yang dilakukan oleh Andayani (2013) yang menyatakan bahwa tidak ada hubungan yang signifikan antara pendidikan ibu dengan pemakaian $\mathrm{KB}$ implant. Berdasarkan penelitian Delima (2015), diperoleh informasi bahwa pada kelompok kasus terdapat 68,2\% dengan tingkat pendidikan yang tinggi, sedangkan pada kelompok control terdapat $92,4 \%$ dengan tingkat pendidikan yang tinggi. Hasil uji statistic diperoleh nilai $p=0,004$ maka dapat disimpulkan bahwa ada perbedaan proporsi pemilihan kontrasepsi implant antara responden pendidikan tinggi dengan responden yang berpendidikan rendah, ada hubungan yang signifikan antara pendidikan dengan pemiihan alat kontrasepsi implant.

Peneliti menyimpulkan bahwa memang benar ada keterkaitan antara tingkat pendidikan seorang wanita untuk menentukan kontrasepsi yang akan digunakan. Dengan tingginya pendidikan seseorang bisa mempengaruhi terhadap pemakaian kontrasepsi, karena dengan pendidikan mempengaruhi pola pemikiran perempuan untuk menentukan kontrasepsi mana yang lebih sesuai.

\section{Hubungan Paritas Dengan Penggunaan KB Implan}

Hasil analisis hubungan antara paritas dengan penggunaan KB Implan diperoleh bahwa ada sebanyak 16 responden $(50,0 \%)$ yang menggunakan KB Implan dan 13 responden $(19,4 \%)$ yang tidak menggunakan $\mathrm{KB}$ Implan dari sejumlah 32 responden yang paritasnya tinggi. Hasil uji statistik diperoleh nilai $\mathrm{p}=0,004$, maka dapat disimpulkan bahwa secara statistik pada alpa 0,05 ada hubungan yang signifikan antara paritas dengan penggunaan KB Implan di Puskesmas Gumawang Kab. OKU Timur Sumatera Selatan Tahun 2020. Dari analisis 
diperoleh pula nilai OR : 4,154 artinya responden yang paritasnya tinggi mempunyai peluang 4,154 kali lebih besar untuk mengalami anemia dibandingkan dengan responden yang paritasnya rendah.

Peneliti berasumsi bahwa jumlah anak hidup mempengaruhi pasangan usia subur dalam menentukan metode kontrasepsi yang akan digunakan. Pada pasangan dengan jumlah anak hidup masih sedikit terdapat kecenderungan untuk menggunakan metode kontrasepsi dengan efektivitas rendah, sedangkan pada pasangan dengan jumlah anak hidup banyak terdapat kecenderungan menggunakan metode kontrasepsi dengan efektivitas yang lebih tinggi.

Hasil penelitian ini sejalan dengan penelitian yang dilakukan oleh Kadir (2012) dimana dalam penelitiannya dijelaskan bahwa Hasil uji statistik Chi-Square didapatkan nilai $\mathrm{p}$ value $<\alpha(0,017<0,05)$, ini menunjukkan bahwa ada hubungan bermakna antara paritas dan pemakaian $\mathrm{Kb}$ implant.

Pengalaman berulang ibu melahirkan mempengaruhi mereka dalam memutuskan dan memilih jenis kontrasepsi yang lebih efektif dalam waktu yang lama.

\section{Hubungan Umur Dengan Penggunaan KB Implan}

Hasil analisis hubungan antara umur dengan penggunaan KB Implan diperoleh bahwa ada sebanyak 21 responden $(39,6 \%)$ yang menggunakan KB Implan dan 32 responden $(60,4 \%)$ yang tidak menggunakan KB Implan dari sejumlah 53 responden yang umurnya risiko tinggi. Hasil uji statistik diperoleh nilai $\mathrm{p}=0,028$, maka dapat disimpulkan bahwa secara statistik pada alpa 0,05 ada hubungan yang signifikan antara umur dengan penggunaan KB Implan di Puskesmas Gumawang Kab. OKU Timur Sumatera Selatan Tahun 2020. Dari analisis diperoleh pula nilai OR : 3,117 artinya responden yang umurnya risiko tinggi mempunyai peluang 3,117 kali lebih besar untuk mengalami anemia dibandingkan dengan responden yang umurnya tidak beresiko.

Penelitian ini sesuai dengan hasil penelitian Andayani (2013) yang menyatakan tidak ada hubungan yang signifikan antara umur ibu dengan pemakaian KB implant. Hasil penelitian sejalan dengan Penelitian di Alabama menemukan hal yang berbeda, bahwa tidak ada hubungan yang signifikan antara umur dengan pemakaian kontrasepsi implant dan non implant dengan nilai $\mathrm{p}=0,37$

Peneliti menyimpulkan bahwa memang benar tidak ada keterkaitan antara umur dengan pemakaian kontrasepsi KB Implant. Lebih banyak responden yang mempunyai umur $>35$ tahun lebih banyak tidak menggunakan $\mathrm{KB}$ implant dibandingkan dengan yang mempunyai umur 20- 35 tahun.

\section{Hubungan Pekerjaan Dengan Penggunaan KB Implan}

Hasil analisis hubungan antara pekerjaan dengan penggunaan KB Implan diperoleh bahwa ada sebanyak 23 responden $(45,1 \%)$ yang menggunakan KB Implan dan 28 responden $(54,9 \%)$ yang tidak menggunakan $\mathrm{KB}$ Implan dari sejumlah 51 responden yang pekerjaannya berat. Hasil uji statistik diperoleh nilai $p=0,001$, maka dapat disimpulkan bahwa secara statistik pada alpa 0,05 ada hubungan yang signifikan antara pekerjaan dengan penggunaan KB Implan di Puskesmas Gumawang Kab. OKU Timur Sumatera Selatan Tahun 2020. Dari analisis diperoleh pula nilai OR : 5,750 artinya responden yang pekerjaannya berat mempunyai peluang 5,750 kali lebih besar untuk mengalami anemia dibandingkan dengan responden yang pekerjaannya ringan.

Jenis pekerjaan seseorang menentukan gaya hidup serta kebiasaan dari individu. Pekerjaan mempunyai peranan yang cukup erat dengan pemikiran dan keputusan yang harus dilakukan demi keberlangsungan karir. Jenis pekerjaan menyangkut berat dan ringannya kategori pekerjaan mempengaruhi jenis pemakaian kontrasepsi yang digunakan. Anggapan kontrasepsi yang kurang aman bagi pekerja keras karena akan menimbulkan efek samping menyebabkan penggunaan kontrasepsi implant cenderung kurang diminati, namun dalam penelitian ini 10 responden (19\%) yang bekerja memilih alat kontrasepsi Implant karena di anggap lebih efektif dan tidak merepotkan dan sebagian besar responden yangbekerja memiliki pengetahuan yang baik tentang KB Implant sehingga menentukan pilihan untuk menggunakan alat kontrasepsi Implant, dan 16 responden (29\%) yang bekerja memiliki pengetahuan yang cukup tentang $\mathrm{Kb}$ Implant.

Penelitian ini berbeda dengan hasil penelitian Andayani (2013) yang menyatakan tidak ada hubungan yang signifikan antara umur ibu dengan pemakaian KB implant. Hasil penelitian juga berbeda dengan Penelitian di Alabama menemukan bahwa tidak ada hubungan yang signifikan antara umur dengan pemakaian kontrasepsi implant dan non implant dengan nilai $\mathrm{p}=0,37$. 
Erma Sugiana, ST Aisjah Hamid dan Erma Puspita Sari, Faktor-Faktor yang Mempengaruhi Penggunaan Kontrasepsi Implant

Tabel 2. Hubungan Variabel Independen dengan Variabel Dependen

\begin{tabular}{|c|c|c|c|c|c|c|c|c|c|}
\hline \multirow[t]{3}{*}{ No } & \multirow[t]{3}{*}{ Variabel Independen } & \multicolumn{4}{|c|}{ Penggunaan KB Implan } & \multirow{2}{*}{\multicolumn{2}{|c|}{ Total }} & \multirow[t]{3}{*}{ Nilai $\mathrm{p}$} & \multirow{3}{*}{$\begin{array}{c}\text { Odd Ratio } \\
95 \% \mathrm{CI}\end{array}$} \\
\hline & & \multicolumn{2}{|c|}{$\mathrm{Ya}$} & \multicolumn{2}{|c|}{ Tidak } & & & & \\
\hline & & $\mathrm{n}$ & $\%$ & $\mathrm{n}$ & $\%$ & $\mathrm{~N}$ & $\%$ & & \\
\hline \multirow[t]{3}{*}{1} & Pendidikan & & & & & & & & \\
\hline & 1. Tinggi & 19 & 38,0 & 31 & 62,0 & 50 & 100 & 0,089 & 2,390 \\
\hline & 2. Rendah & 10 & 20,4 & 39 & 79,6 & 49 & 100 & & \\
\hline \multirow[t]{3}{*}{2} & Paritas & & & & & & & & \\
\hline & 1. Tinggi & 16 & 50,0 & 16 & 50,0 & 32 & 100 & $0,004 *$ & 4,154 \\
\hline & 2. Rendah & 13 & 19,4 & 54 & 80,6 & 67 & 100 & & \\
\hline \multirow[t]{3}{*}{3} & Umur & & & & & & & & \\
\hline & 1. Risiko Tinggi & 21 & 39,6 & 32 & 60,4 & 53 & 100 & $0,028 *$ & 3,117 \\
\hline & 2. Tidak Risiko & 8 & 17,4 & 38 & 82,6 & 46 & 100 & & \\
\hline \multirow[t]{3}{*}{4} & Pekerjaan & & & & & & & & \\
\hline & 1. Berat & 23 & 45,1 & 28 & 54,9 & 51 & 100 & $0,001 *$ & 5,750 \\
\hline & 2. Ringan & 6 & 12,5 & 42 & 87,5 & 48 & 100 & & \\
\hline
\end{tabular}

Sumber: Data diolah

\section{Analisis Multivariat \\ Pemilihan Variabel Kandidat Multivariat}

Pemilihan variabel kandidat dilakukan melalui analisis bivariat. .Hasil uji bivariat yang mempunyai nilai $\mathrm{p} \leq 0,25$ maka variabel tersebut dapat masuk ke dalam model multivariate, sedangkan variabel yang mempunyai nilai $\mathrm{p}>0,25$ tidak di ikutsertakan dalam analisis multivariate. Dalam penelitian ini ada 4 variabel independent yang masuk dalam analisis multivariate yaitu, pendidikan, paritas, umur dan pekerjaan, seperti pada table berikut 3 ini:

Tabel 3. Variabel Independent yang Masuk Kandidat Model Multivariat.

\begin{tabular}{clc}
\hline No & $\begin{array}{l}\text { Faktor Berpengaruh Terhadap KB } \\
\text { Implan }\end{array}$ & p value \\
\hline 1 & Pendidikan & 0,053 \\
2 & Paritas & 0,002 \\
3 & Umur & 0,014 \\
4 & Pekerjaan & 0,000 \\
\hline
\end{tabular}

Sumber: Data diolah

\section{Pembuatan Model Faktor Penentu Terhadap Penggunaan KB Implan}

Dari hasil analisis regresi logistic pada model akhir (fit model) didapat 2 variabel yang bermakna secara statistic hubunganya dengan penggunaan KB Implan. Kedua variabel tersebut adalah variabel paritas dan pekerjaan. Kemudian untuk mengetahui variabel mana yang paling dominan pengaruhnya terhadap penngguaan KB Implan dapat dilihat pada nilai Exp (B). Dari model akhir ternyata variabel yang paling besar pengaruhnya terhadap penggunaan KB Implan adalah variabel pekerjaan.

Tabel 4. Model Akhir Regresi Logistik antara 2 Variabel Independen Dengan KB Implan

\begin{tabular}{lcccc}
\hline Variabel & B & P Wald & OR & 95 \% CI \\
\hline Paritas & 1,184 & 0,017 & 3,268 & $1,234-8,654$ \\
Pekerjaan & 1,566 & 0,003 & 4,787 & $1,680-13,645$ \\
Constant & $-3,214$ & 0,002 & 0,040 & \\
\hline
\end{tabular}

Sumber: Data diolah

\section{Uji Interaksi antar Variabel Independen}

Dari uji interaksi, terlihat tidak ada interaksi antara pekerjaan dengan paritas ( $\mathrm{p}$ value : 0,109). Keadaan semacam ini memberikan petunjuk bahwa hubungan pekerjaan dengan penggunaan KB Implan tidak memberikan efek yang berbeda untuk responden yang paritasnya tinggi dan yang paritasnya rendah.

Tabel 5. Uji Interaksi Antara Pekerjaan dan Paritas Terhadap Penggunaan KB Implan

\begin{tabular}{lccc}
\hline Interaksi & -2 Loglikehood & G & P value \\
\hline Paritas & 97,943 & 21,798 & 0,450 \\
Pekerjaan & 97,943 & 21,798 & 0,486 \\
Pekerjaan*Paritas & 97,943 & 21,798 & 0,109 \\
\hline
\end{tabular}

Sumber: Data diolah

\section{SIMPULAN}

Hasil analisis menunjukkan bahwa paritas (p value:0,004) dan umur ( $\mathrm{p}$ value:0,028), pekerjaan ( $\mathrm{p}$ value:0,001), memiliki hubungan signifikan dengan penggunaan $\mathrm{KB}$ Implan, sedangkan pendidikan $(\mathrm{p}$ value:0,089) tidak memiliki hubungan yang signifikan dengan penggunaan KB Implan. Berdasatkan model akhir analisis multivariat variabel yang paling besar pengaruhnya terhadap penggunaan KB Implan adalah variabel pekerjaan.

\section{DAFTAR PUSTAKA}

Andayani, 2012, Pendidikan Karakter Perspektif Islam, Bandung: PT remaja rosdakarya.

Atmodjo, 2011, Kesehatan Masyarakat Ilmu dan Seni, Rineka Cipta Jakarta.

BKKBS, 2019, Laporan Badan Keluarga Berencana Provinsi Sumatera Selatan Kabupaten OKU Timur.

Delima, 2015. Identifikasi kebutuhan pengguna untuk aplikasi permainan edukasi bagi anak usia 4 sampai 6 tahun

Hastono, 2018, Analisis Data Pada Bidang Kesehatan, Rajawai, Jakarta.

Kadir, A. 2012. Hubungan Paritas dan Pekerjaan Akseptor dengan Pemakaian Kontrasepsi Implant 
Erma Sugiana, ST Aisjah Hamid dan Erma Puspita Sari, Faktor-Faktor yang Mempengaruhi Penggunaan Kontrasepsi Implant

di BPS Kresna Hawati Kel. Karang Jaya Palembang. Poltekkes Kemenkes Palembang.

Marliza, Anantasia. 2013. Faktor-faktor yang mempengaruhi Rendahnya minat Ibu untuk memilih implant sebagai Alat Kontrasepsi di Kelurahan Terjun Kecamatan Medan Marelan. Universitas Pasir Pengairan.

Sari, EI, 2016. Faktor-faktor yang Berhubungan dengan Rendahnya minat Ibu terhadap Penggunaan Metode Kontrasepsi Jangka Panjang di BPS Sri Romdhati Semin Gunung Kidul. Universitas Aisiyah Yogyakarta.

Samandari, G., 2010. Adolescent sexual behavior and reproductive outcomes in Central America: trends over the past two decades. Int Perspect Sex Repord Helath. 36(1): 26-35.

Samekto, Bambang. 2008. PerananAgama dalam proggram KB Nasional". http://pustaka.bkkbn.go.id/index.php?option=com _content\&task=view\&id=109\&Itemid=9. Diakses pada 5 Mei 2020

Survey Demografi dan Kesehatan Indonesia (SDKI) Tahun 2017

Word Health Organization, 2017. Word Health Statistic 2014 